\title{
Effect of Economic Growth on the Logistics Sector in India
}

\author{
Gunjan Malhotra, Sita Mishra \\ Institute of Management Technology, Ghaziabad, India \\ Email: gmalhotra@imt.edu,smishra@imt.edu
}

How to cite this paper: Malhotra, G. and Mishra, S. (2019) Effect of Economic Growth on the Logistics Sector in India. Theoretical Economics Letters, 9, 210-222. https://doi.org/10.4236/tel.2019.91016

Received: December 27, 2018

Accepted: February 12, 2019

Published: February 15, 2019

Copyright $\odot 2019$ by author(s) and Scientific Research Publishing Inc. This work is licensed under the Creative Commons Attribution International License (CC BY 4.0).

http://creativecommons.org/licenses/by/4.0/

\begin{abstract}
Purpose: The aim is to attempt to explore the effect of selected economic growth indicators on the net profits in the logistics sector in India. Methodology: The research type used is causal research. The data are collected for the period of 1991-92 to 2016-17 from CMIE, RBI and government websites. The paper tries to establish the relationship among the independent variables such as the change in taxes, change in inflation rate and the change in GDP of Indian services sector on the dependent variable as profits of the Indian logistics industry. Findings: Results indicate that the tax expenses and inflation rate have a negative impact on the profit of logistics sector whereas the change in GDP service sector has a positive impact on the profit of the logistics sector. However, GDP service sector affects the profit of transportation industry less than the impact in comparison to the tax rate and inflation. Originality: This study provides the foundation for future research in the logistics sector. In today's globalization and digitalization and with the advent of tax reforms like GST, this research is relevant with regard to determining the effect of taxation, inflation, and GDP on the logistics sector in India.
\end{abstract}

\section{Keywords}

Logistics Sector, Multiple Linear Regression, Economic Growth

\section{Introduction}

The logistic sector is considered to be an important sector to facilitate increased international trade in consequence of globalization and digitalization [1] [2]. It plays a key role in economic development and growth of a country because the logistics sector helps to transport goods across the nation. The growth in the field of logistics sector results in competitiveness among the countries and thus it becomes a vital element of economic development and growth of the country 
[3]. The innovative and new technologies have provided high efficiency and extra joint operating models [4]. The logistics sector has changed the way marketplace behaves and became apparent few years ago.

Logistics is a kind of supportive action that involves activities such as planning, implementation, and control of the movement of goods and people within companies. These activities help and offer support in supply chain process [5] [6]. These logistics activities promote knowledge, innovations and new strategies to achieve profitability for the company [7]. The manufacturers ensure that their new products reach the end customer in less time, and thus they outsource their logistical activities to logistics service providers (LSP) [8]. These logistics activities by the business firms include storage and retrieval of information on goods, material management, and plan of processing strategies [9] [10]. They tend to satisfy their needs for logistical services such as transportation, warehousing, and storage, distribution, sorting facilities, shipping, cargo handling, and inland waterways [11] [12]. Mainly, logistics service providers (LSP) range from first-party logistics to fourth-party logistics (1PL-4PL). The LSP categorized as 7PL provide third-party logistics (3PL or TPL) and 4PL services. On the top LSP, logistics develop more asset-light and more planning and design-oriented activities [13]. The efficient logistics system indicates economies of scale [14].

The transportation and logistics contribute against the growth of any economy. The global logistics sector is with a valuation of USD 4 trillion. On average, logistics accounts for anywhere between $8 \%$ and $20 \%$ of a country's Gross Domestic Product (GDP). India's logistics cost represents 13\% of GDP, approximately USD 260 billion [15] [16], whereas the logistics cost in the US is around 9\%; the reduction in these logistics cost will lend a competitive advantage to Indian exports [17]. The development in the logistic sector will result in ease of production, and reduce transportation costs and distribution costs. The precise planning of logistical activities is vital to get cost and effectiveness for its nations [18]. Besides, the rise in international trade volume leads to improve the logistic volume of the firms. Logistics has presently become the important component of trade as it takes the active role in the economic growth and development of the country. Thus supply chain barriers need to be reduced if the economy needs to optimize its GDP and thereby increase its international trade [19]. Thus, benefits from the reduction in tariffs will reduce logistics cost and thus the GDP of the economy will be increased [20] [21]. In this paper, therefore, we study how the economic growth indicators such as GDP, inflation and tax rate impact the Indian logistics sector's profitability. The efficiency of the logistics sector has increased after the introduction of Goods and Service Tax (GST) which is expected to minimize the spending on this sector and which will result in economic growth. The paper makes an attempt to shows economic factors impact on the logistics sector of the Indian economy. Also, after GST implementation, this research could be useful to further investigate the impact of the GST regime on the net profit of Indian transportation sector.

The paper was planned as follows: in the first section we introduce the logis- 
tics sector and its importance in the economic growth of the economy. Second, we discuss the literature review and the conceptual framework of the paper. After that the methodology will be deliberated, followed by results and discussion section. At last, managerial impacts and conclusions of the study will be discussed.

\section{Literature Review}

Logistics is becoming a major fundamental economic sector as an industry. In recent years, several papers have focused their attention on the efficiency in the logistics industry taking into account various factors.

Logistics sector enhances the productivity and competitiveness of various manufacturing firms. In Italy, the size and geographical location of the firms determine the Italian logistics firm efficiency score [22]. In Texas, US customers requested 3PL's or fulfillment providers to use ShipStation to provide parcel shippers inspected options for outsourcing parcel fulfillment. That is possible due to integrations into e-commerce selling platforms and the variety of carrier choices [23]. In United Arab Emirates (UAE) shipping and logistics firm, Aramex, serves its terrestrial markets by indulging into partnerships with other logistics and transportation companies across the globe. They supported e-commerce within supply chain management and shipping services, product storage and order fulfillment [24].

A review of logistics and transport sector has explained transport system that supports international economic relations to create a world network of exchange of goods and transfer of the capital goods among nations using several transport modes [10]. The world economy has been transformed and in this process, the logistics chain is the essential part of the manufacturing process [25]. The developments in the logistic sector may impact the economic growth for OECD countries. The panel data analysis used the proxy of development of logistics sector which included the variables such as infrastructure investments, railway transportation, road transportation, airline transport, telephone lines, and internet users [26]. The Chinese logistics industry proved that the economic growth of China increase by using correlation and regression techniques. The economic growth is impacted by the variables such as value added, total employment of the logistics sector, freight volume, freight turnover and new fixed assets investments [27]. The co-integration analysis of logistics infrastructure investment and regional economic growth in central China shows that the investment in fixed assets for the logistics industry will contribute to regional economic growth. This increased growth of logistics will improve and promote the fixed assets investment in the economy [28]. The economic growth may also impact the logistics industry through the relationship between FDI inflows and the logistics sector of the economy [29]. The economic growth refers to the growth of industries that contribute against the changing growth of the economy through contacting other industries having input-output relations. That is re- 
ferred to as the growth pole theory [30]. In the same way the logistics industry influences other economic industries as it helps to develop and strengthen the investment environment [31].

To improve the efficiency of the supply chain of the firm, the relationship between supply chain integration, supply chain responsiveness, and competitive advantage of the firm becomes important. Also, logistics and supply chain management derives benefits from advanced and innovative information technology, inventory management and buyer-supplier relationship [32]. That will lead towards the growth of the logistics industry, and the industrial consumer's behavior will change. The emergence of new information technologies has brought up the concept of block-chain technology used to trace the movement of goods in the logistics sector. The logistics firms are working on up-gradation of their research projects to evaluate, test and create awareness of such new technologies [33].

The logistics chain needs to focus on the development of logistics, transport-related sectors based on a past review, inter-relationships of transportation and logistics [34]. The growth of transport infrastructure including railways, roadways, and airways along with gross capital formation will lead towards sustainable economic growth in India [35] [36]. The logistics performance indicator has a negative impact on export likelihood and positive influence on export capacity and will help to improve the policies of the economy [37]. That will move forward towards sustainable development.

The Indian economy has provided the logistics sector with the infrastructure status that includes cold chain and warehousing facilities. That will attract more funding to this sector at competitive rates for all logistics segments, and thus the cost of exports will be high. That will help facilitate more competitive rates to grow logistics sector, and the Indian goods will be less competitive in the global market [35] [38]. The tax on the warehouse, storage, and other labor services increased from $15 \%$ to $18 \%$ after GST was implemented. Therefore, 3PL provider would have more incentive and the high degree of values addition where input tax credit could be claimed. The entry in different states would become easy, and the delays in the transportation cost will be reduced [39].

The consumers have varied characteristics with different products and thus the emergence of the unique set of opportunities for firms to sustain supply chain profitability. The firm needs to prepare them from the challenges of the macro-factors that may impact the supply chain. These factors may include the cities, supply chain infrastructure, the emergence of new channels of distribution, increased globalization, changes in the regulatory climate like GST implementation, affordable technologies and big data. However, the volatility in supply and demand will continue [40]. The logistics industry is mainly unorganized and cluttered in India. It is difficult to attract new recruiters from less attractive pay and incentives in this industry [41].

As evident from the discussion above the research papers have focused on the 
infrastructure needed to develop the logistics industry [31]. Some articles focused on the improvement in supply chain management due to the advancement of the logistics sector and how logistics are important for the transportation system [42]. Some research papers are on how infrastructure status to logistics industry will help it to grow and the relationship between FDI inflow and the logistics industry. Furthermore, some papers are on how logistics substantially supports international economic relations and plays a primary part in creating a world network of exchange of goods [10]. The pricing of the goods and services may vary due to inefficient supply chain management. In India, on July 1, 2017 an indirect value-added tax was levied on the manufacture, sale, and consumption of goods, and services at the national level. This recent change in the taxation system of India is known as Goods and Services Tax (GST). It is applicable for all goods and services that are supplied by the manufacturer or seller. The liability to pay this tax arises at the time of supplying the goods and services. That tax is paid by the end consumer only by the last supplier in the supply chain [42]. This new Indian tax regime may have an impact on the supply chain profitability. This is the first attempt to understand the factors that may impact the profits incurred through the efficient supply chain of the organization.

Thus the paper analyzes the effects of inflation, gross domestic product (GDP) and impact of the tax on the net profit (or income) of the logistics firms of India. The paper includes dependent variable as profits after tax because the uncertain environment of GST in Indian markets have changed and rationalized the Indian GST tax regimes and thus the profits after tax to the logistics sector is selected for analysis. The research hypothesis for the paper is formulated as:

HO (Null Hypothesis): The changes in the economic growth indicators such as GDP, tax expenses and inflation have no impact on the changes in the profits after tax (PAT) of transportation or logistics industry of India.

H1 (Alternative Hypothesis): The changes in the economic growth indicators such as GDP, tax expenses and inflation have a positive impact on the amount of change in the profits after tax (PAT) of transportation or logistics industry of India.

\section{Methodology}

Before you begin to format your paper, first write and save the content as a separate text file. Keep your text and graphic files separate until after the text has been formatted and styled. Do not use hard tabs, and limit use of hard returns to only one return at the end of a paragraph. Do not add any kind of pagination anywhere in the paper. Do not number text heads-the template will do that for you.

The causal research is used wherein the impact of the change in taxes, change in inflation rate and change in GDP of Indian services sector on the Indian logistics industry is taken for the study period 1991-92 to 2016-17. The impact of liberalization and economic reforms in Indian economy were seen after 1992, 
which also impacted the logistics sector of the economy. Because of liberalization more goods were exported and imported from India and thus the expenditure in logistics sector increased that resulted into increased profitability in this sector of the economy. The new tax regime i.e. Goods and Services Tax (GST) introduced in India on July 1, 2017, will positively affect the net profit of the logistics sector of India. The data for the net profit of transportation sector of India, tax expenditure, inflation rate and GDP of the service sector have been collected from Centre for Monitoring Indian Economy (CMIE) and Reserve Bank of India (RBI) websites for the study period.

The linear regression analysis is used to test if the independent variables considered have a significant positive or negative impact on the response variable [43]. We checked for the normality of the data and found that the data was not normal. We took the data values with a difference of the lag period and re-checked the data for the normality test. The data was found to be normal and therefore, we applied simple linear regression model for our analysis. The regression model is given below: Net Profits of transportation sector $r_{t}=\beta_{1}+\beta_{2}$ (GDP service sector $)+\beta_{3}$ (Tax Expenditure $)+\beta_{4}$ (Inflation rate $)+\mathrm{U}_{\mathrm{t}}$. Where the net profit of transportation sector $\left(\mathrm{Y}_{\mathrm{t}}\right)$ is the response variable and GDP service sector (X1), tax expenditure (X2) and inflation rate (X3) are the independent variables. First, the normality test on the dependent variable has been done, and then all the independent factors have been normalized, so that to get a better comprehension of the results after the analysis. To check for autocorrelation among the error terms the Durbin-Watson $d$ statistics test has been performed. The $d$ statistic is calculated as follows:

$$
d-\text { statistic }=\frac{\sum_{i}^{t}\left(e_{t}-e_{t-1}\right)^{2}}{\sum_{i}^{t} e_{t}^{2}}
$$

where $t$ is the number of observations. If $d=2$ there is no autocorrelation, if $d>$ 2 negative autocorrelations and if $d<2$ positive autocorrelations is there in the model [44]. Some researchers believe if $\mathrm{d}$ statistic value is between 1.8 and 2.2 then the autocorrelation problem is not severe and can be treated as no problem of autocorrelation or serial correlation. In order to have predictors linearly independent from one and others the multicollinearity check has been performed [45]. To evaluate the level of multicollinearity among independent variables the Variance Inflation Factor (VIF) is used and calculated as follows:

$$
V I F_{i}=\frac{1}{1-R_{i}^{2}}
$$

where, $R_{i}^{2}$ is the coefficient of determination in a regression of its predictor on all others. Many researchers use a VIF of 5 and others use a VIF of 10 as a critical threshold upper limit, which corresponds, respectively, a $R_{i}^{2}$ values of 0.80 and 0.90 . To know if the data had equal variance the scatter plot method is used to check for homogeneity in the model. If the scatter plot indicates a funnel-shaped the variables is not homogenous i.e. heterogeneity is present in the 
model.

\section{Results and Discussion}

The India industries spend around 14\% of its GDP on the logistics sector [46]. There is plenty of competition among the domestic firms in every industrial sector. Indian economy has a consumer base of over a billion people and is the fastest growing economy in the world. India is rich in providing cheap skilled labor, technological resources and varied talent of its citizens. But the inadequacy of organized economic activities creates the challenge for the logistics sector of the economy. The infrastructural difficulty emerges in the economy due to which the logistics cost in the economy is comparatively high when compared to other nations. The Indian expenditure on infrastructural activities should increase over the years which have somewhat tried to control huge logistics cost. India's investments done in roads, railways and airways are represented in Table 1 from 2002 to 2015. By the end of 2004, Indian investment of roadways was INR 1871 million which increased to INR 6360 million in 2010 and INR 15108 in 2015. This enormous increase in the investments in roadways must be done on express and national highways, connectivity with rural markets, etc. Even though huge investments are done in developing the infrastructure of roads but, still the logistics cost have not been reduced mainly due to the poor quality of Indian roads, and thus the safety of transportation of goods arise. The Indian railway network is the second largest railroad system in the world covering a route length of $81,511 \mathrm{~km} \mathrm{[46].} \mathrm{In} 2004$ the investments in the railway network signified 2331 million INR whereas this increased to INR 5150 million in 2010 and further increased to INR 11,462 million. The quality of rail infrastructure is improved but the speed of freight movement is slow and the turnaround time is still low, which is a main concern for the logistics sector of the economy. In Airways the investment was only 4 million INR in 2004 which increased to 208 million INR in 2010 and further increased to 356 million INR by the end of 2015. The domestic cargo and international cargo capacities of airways required to expand if the logistics cost reduces and the firms look forward to expand its profits for the transportation sector of the economy [47]. Here companies opt for global sourcing strategies to reduce cost and to enhance the quality of their product. That shows that India's investments in the logistics sector have increased several folds over the years and initial investments indicate infrastructure development of roadways and railways as compared to airways.

Table 2 illustrates the volume of freight progress in million metric tonnes per kilometers (kms) via railway and road in India from 1991 to 2017. In roadways, the volume of freight has increased from 180,778 million tonnes kms in 1991-92 to $1,144,500$ million tonnes $\mathrm{kms}$ in 2010 , and by the end of 2017 , it has increased many folds to 2,210,850 million tonnes kms. That clearly shows that the volume of goods transferred through roadways have ever been increasing and thus the investments in this sector. Similarly, in the railway network has also developed drastically from 256,890 million tonnes $\mathrm{kms}$ in 1991-92 to 600,546 million 
tonnes $\mathrm{kms}$ in 2010 and by the end of 2017 it was 656,444 million tonnes $\mathrm{kms}$. That justifies the importance of investment to be made in this sector, and hence the bullet train concept has emerged in the Indian economy. The volume has remarkably increased after globalization and liberalization policies adopted by the Indian economy. That shows that movement of goods from the place of manufacturing to reach the final consumer has increased laying further increase in the transportation and logistics sector of the economy. That will increase the GDP of the economy and thus will have a positive impact on the increment of the logistic sector. These investments will further generate tax expenditure by the government and changes in inflation component will also take place. These factors may further impact the profits of the transportation sector of the economy.

To understand the effect of the GDP service sector, tax expenditure and the inflation rate on the net profits of the transportation sector in the Indian economy using multiple linear regression technique. To perform the regression analysis, the normality of all the variables included in the model were checked. Few variables were not normal so, we took the difference of these variable with the lag of one-time period and re-checked the normalcy of the data. The dependent variable and all the independent factors have been normalized after conducting the normality test. The regression equation used for analysis is written as $\mathrm{Y}_{\mathrm{t}}=\beta_{1}$ $+\beta_{2} \mathrm{X}_{1}+\beta_{3} \mathrm{X}_{2}+\beta_{4} \mathrm{X}_{3}+\mathrm{U}_{\mathrm{t}}$, where $\beta$ s are regression coefficients and $\mathrm{Y}_{\mathrm{t}}=\mathrm{Net}$ Profits of transportation sector, $\mathrm{X}_{1}=$ GDP service sector, $\mathrm{X}_{2}=$ Tax Expenditure $\mathrm{X}_{3}=$ Inflation rate, and $\mathrm{U}_{\mathrm{t}}$ is the error term. The SPSS version 24 was used to perform regression analysis techniques. The data was also tested for the problem of autocorrelation, multicollinearity, and heteroscedasticity in the regression equation. The calculated regression equation can be written as follows:

$$
y=2167.006+0.008 X_{1}-0.59 X_{2}-4430.224 X_{3}+U_{t} ; R^{2}=0.706
$$

Table 1. Indian investment in transportation sector-railways, roadways and airways.

\begin{tabular}{cccc}
\hline \multirow{2}{*}{ Year } & \multicolumn{3}{c}{ Investment (in millions INR) } \\
\cline { 2 - 4 } 2004 & Railways & Roadways & Airways \\
2005 & 2331 & 1871 & 4 \\
2006 & 2811 & 3258 & 63 \\
2007 & 3223 & 4035 & 4 \\
2008 & 3927 & 4384 & 17 \\
2009 & 4722 & 4722 & 21 \\
2010 & 4807 & 4807 & 133 \\
2011 & 5150 & 6360 & 208 \\
2012 & 4944 & 5617 & 189 \\
2013 & 6208 & 6208 & 876 \\
2014 & 5929 & 8475 & 781 \\
2015 & 8778 & 9773 & 721 \\
\hline
\end{tabular}

Source: https://data.oecd.org/transport/infrastructure-investment.htm\#indicator-chart. 
Table 2. Indian volume of freight progress (in million tonnes $\mathrm{kms}$ ).

\begin{tabular}{ccc}
\hline \multirow{2}{*}{ Year } & Volume of freight progress (in million tonnes kms) \\
\cline { 2 - 3 } $1991-92$ & Railways & Roads \\
$1995-96$ & 256,890 & 180,778 \\
$2001-02$ & 273,520 & 287,778 \\
$2005-06$ & 333,200 & 494,000 \\
2008 & 439,596 & 643,000 \\
2009 & 551,448 & 933,700 \\
2010 & 551,448 & $1,021,600$ \\
2011 & 600,546 & $1,144,500$ \\
2012 & 625,723 & $1,144,500$ \\
2013 & 667,607 & $1,407,800$ \\
2014 & 665,810 & $1,508,000$ \\
2015 & 665,810 & $1,653,600$ \\
2016 & 681,696 & $1,822,300$ \\
2017 & 654,481 & $2,023,846$ \\
\hline
\end{tabular}

Source: https://data.oecd.org/transport/infrastructure-investment.htm\#indicator-chart.

The coefficient of determination is 0.706 , which means $70.6 \%$ of the variations in the PAT of the transportation sector is impacted by GDP service sector, tax expenditure and inflation rate. Hence the model selected is the good fit. The regression equation shows that the coefficient of GDP service sector is positive and statistically significant at $5 \%$ level of the significance impact on the net profits of the transportation sector. Whereas the coefficient of tax expenditure and inflation rate have a negative but significant impact on the net profits of the transportation sector. That means that the one-unit increase in the GDP service sector of the Indian economy impacts the net profits of the logistics sector by 0.008 units. Moreover, the coefficient of tax expenditure is -0.59 which means the one-unit change in tax expenditure will decrease PAT by 0.59 units. Also, the coefficient of inflation rate is -4430.224 which is negative and statistically significant at $5 \%$ level of significance. That means the one-unit increase in inflation rate will decrease PAT by 4430.224 units. Hence the null hypothesis is rejected at $5 \%$ level of significance. The model is free from the problem of autocorrelation as the value of d-statistics is 1.801 which is nearing 2 and hence no problem of autocorrelation in the model. Also, the calculated VIF value is less than 5 and hence the model is free from the problem of multicollinearity. Also, the model is free from heteroscedasticity problem as there is no pattern seen in the scatter plot of the model.

Thus, the net income of the transportation industry of India decreases with the increase in the tax expenditure and inflation rate in the Indian economy 
whereas the increase in the GDP of the service sector of the nation the net income of the transportation industry also increases. The result can be validated by the observation that the transportation sector forms a small part of the services sector of India and also there has not been any drastic jump in the GDP of this sector. According to the regression analysis, the tax expenditure has a negative impact on the net profit. Rise in inflation in the Indian economy has also an immense negative impact on the net income of the transportation sector of India. As the inflation rate increase the net income of the transportation sector decreases drastically.

\section{Conclusions}

The logistics is one of the major economic sectors not only as an industry in itself but also for its contribution upon manufacturing firms' productivity. With government plan of "Make in India" and boosting local manufacturing sector and the implementation of new tax regime i.e. GST, the study of factors affecting logistics sector in India has become more important. This is the reason why the study has investigated Indian logistics industry through an analysis based on multiple regression method aiming at estimating the impact of the tax, inflation, and GDP on the income of logistics firms of India.

As per the results, it has been observed that $70.6 \%$ variation in net profit after tax of the transportation sector of India can be explained by the change in tax expenditure, inflation rate, and GDP. With the advent of GST which results in the elimination of the cascading effect of taxes and generating only one tax, the profit will increase since the tax is negatively related to profit at $5 \%$ level of significance. Also, GST will result in fewer and geographically effective locations of warehouses which will minimize the transportation costs and in turn cause the per unit price of the products to fall as compared to previous prices. This will eventually lead to high demand of products, thus increasing the GDP. As GDP is positively related to the profit, the profits of the logistics sector will increase. The study shows the impact of inflation on the profit of the transportation sector which can motivate the authority in making the decisions of monetary policies.

Thus, logistics is the key factor in the global supply chain management. With the economic growth of the country the investments in the logistic sector and transport infrastructure increases more than the GDP of the economy. The investments in the roadways, railways, and airways of the economy also increase and are modernized and expanded and are sometimes imported from the world. The firms in India are becoming aware of the benefits of reduction in the logistics cost [46]. In this respect infrastructural development is important and the government of India has taken some initiatives to facilitate this sector by investing in the roadways, railways and airways [47].

The limitations of the study include effective implementation of the GST by the government of India. The government is taking corrective measures to revise its GST tax system. Thus, the impact of GST regime on the net profits of the lo- 
gistics sector for the Indian firms may be tested once the GST system is established in the long run. Further, the study can apply models such as the Granger Causality test, ARCH, GARCH, etc. to find if GDP, inflation and tax regime have an impact on logistics profitability or vice versa.

\section{Conflicts of Interest}

The authors declare no conflicts of interest regarding the publication of this paper.

\section{References}

[1] Mayer, J. (2018) Digitalization and Industrialization: Friends or Foes?

[2] Panitz, R. and Glueckler, J. (2017) Rewiring Global Networks at Local Events: Congresses in the Stock Photo Trade. Global Networks, 17, 147-168. https://doi.org/10.1111/glob.12134

[3] Viswanadham, N and Gaonkar, R (2003) Leveraging Logistics to Enhance Indian Economic Competitiveness. CII Logistics.

[4] Saucedo-Martínez, J.A., Pérez-Lara, M., Marmolejo-Saucedo, J.A., Salais-Fierro, T.E. and Vasant, P. (2017) Industry 4.0 Framework for Management and Operations: A Review. Journal of Ambient Intelligence and Humanized Computing, 1-13.

[5] Neubert, G., Ouzrout, Y. and Bouras, A. (2018) Collaboration and Integration through Information Technologies in Supply Chains.

[6] Fox, M.S., Barbuceanu, M. and Teigen, R. (2001) Agent-oriented Supply-Chain Management. In: Information-Based Manufacturing, Springer, Boston, MA, 81-104. https://doi.org/10.1007/978-1-4615-1599-9_5

[7] Sternad, M., Lerher, T. and Gajsek, B. (2018) Maturity Levels For Logistics 4.0 Based on Nrw's Industry 4.0 Maturity Model. Business Logistics in Modern Management, 18, 695-708.

[8] Lai, K.H. (2004) Service Capability and Performance of Logistics Service Providers. Transportation Research Part E: Logistics and Transportation Review, 40, 385-399. https://doi.org/10.1016/j.tre.2004.01.002

[9] Chatterjee, L. and Tsai, C. (2002) Transportation Logistics in Global Value and Supply Chains. Working Paper No. 2002G. Boston University, Boston. https://www.bu.edu/transportation/CTS2002G.pdf

[10] Kherbash, O. and Mocan, M.L. (2015) A Review of Logistics and Transport Sector as a Factor of Globalization. Procedia Economics and Finance, 27, 42-47. https://doi.org/10.1016/S2212-5671(15)00969-7

[11] Saksoft (2018) Transportation and Logistics-The Nervous System of an Economy. Saksoft-Your Digital Transformation Partner. https://www.saksoft.com/transportation-logistics-nervous-system-economy/

[12] Lieb, R. and Miller, J. (2002) The Use of Third-Party Logistics Services by Large US Manufacturers, the 2000 Survey. International Journal of Logistics, 5, 1-12. https://doi.org/10.1080/13675560110114270

[13] Sinkovics, R.R. and Roath, A.S. (2004) Strategic Orientation, Capabilities, and Performance in Manufacturer-3PL Relationships. Journal of business Logistics, 25, 43-64. https://doi.org/10.1002/j.2158-1592.2004.tb00181.x

[14] Tipping, A. and Kauschke, P. (2016) Shifting Patterns, the Future of the Logistics Industry. Price Waterhouse Coopers, Phoenix. 
[15] Frank, K. (2018) The Indian Warehousing Opportunity Report 2018: Knight Frank.

[16] Kumar, A. and Ramesh, A. (2018) Modelling Intermodal Freight Transportation Promotion for Sustainable Supply Chain in India. In: Sustainable Operations in India, Springer, Singapore, 115-137. https://doi.org/10.1007/978-981-10-8010-4_7

[17] Sharma, N.K. and Kuswaha, G.S. (2017) A Study on Indian Logistics Network and Its impact on Economic Growth. IUP Journal of Supply Chain Management, 14, 38-60.

[18] Kalra, G., Chotia, V. and Goel, A. (2016) Investigating the Relationship between Transport Infrastructure and Economic Growth: The Case of India. Indian Journal of Economics and Development, 12, 315-320. https://doi.org/10.5958/2322-0430.2016.00141.4

[19] World Bank (2013) Report: Reducing Supply Chain Barriers Could Increase Global GDP up to 6 Times More than Removing All Import Tariffs.

http://www.worldbank.org/en/news/press-release/2013/01/23/report-reducing-supp ly-chain-barriers-could-increase-global-gdp-6-times-more-than-removing-all-impo rt-tariffs

[20] Doherty, S., Philip, R., Willink, B.T. and Correa, A. (2013) Enabling Trade: Valuing Growth Opportunities. World Economic Forum, 13-20.

[21] Trade, E. (2013) Valuing Growth Opportunities. World Economic Forum.

[22] Ferrari, C., Migliardi, A. and Tei, A. (2018) A Bootstrap Analysis to Investigate the Economic Efficiency of the Logistics Industry in Italy. International Journal of Logistics Research and Applications, 21, 20-34. https://doi.org/10.1080/13675567.2017.1353597

[23] Berman, J. (2017) ShipStation Fulfillment Program Provides Parcel Shippers with. Logistics Management.

https://www.logisticsmgmt.com/article/shipstation_fulfillment_program_provides_ parcel_shippers_with_vetted_option

[24] Kaplan, M. (2017) Aramex Expands E-Commerce Logistics beyond Middle East. Practical Ecommerce.

https://www.practicalecommerce.com/aramex-expands-ecommerce-logistics-beyon d-middle-east

[25] Yoon, H.Y., Bang, H.S. and Woo, S.H. (2016) A Comparative Study on the Logistics Research between International and Korean Journals. The Asian Journal of Shipping and Logistics, 32, 149-156. https://doi.org/10.1016/j.ajsl.2016.09.003

[26] Hayaloğlu, P. (2015) The Impact of Developments in the Logistics Sector on Economic Growth: The Case of OECD Countries. International Journal of Economics and Financial Issues, 5, 523-530.

[27] Liu, S. (2009) A Research on the Relationship of Logistics Industry Development and Economic Growth of China. International Business Research, 2, 197. https://doi.org/10.5539/ibr.v2n3p197

[28] Hu, K., Gan, X.Q. and Gao, K. (2012) Co-Integration Model of Logistics Infrastructure Investment and Regional Economic Growth in Central China. Physics Procedia, 33, 1036-1041. https://doi.org/10.1016/j.phpro.2012.05.170

[29] Wang, Y. and Wang, L. (2010) The Economic Growth Effect of Logistics Industry FDI Analysis. IBusiness, 2, 377. https://doi.org/10.4236/ib.2010.24049

[30] Francois, P. (1981) Note on the Concept of Growth Poles. Development Economics and Policy Reading, 182-187.

[31] Dai, Q. and Yang, J. (2013) Input-Output Analysis on the Contribution of Logistics Park Construction to Regional Economic Development. Procedia-Social and Beha- 
vioral Sciences, 96, 599-608. https://doi.org/10.1016/j.sbspro.2013.08.070

[32] Singh, A.P. (2016) Do Technology Spillovers Accelerate Performance of Firms? Unravelling a Puzzle from Indian Manufacturing Industry. Economics and Applied Informatics, 22, 108-120.

[33] De, N. (2017) US Logistics Agency Launches Blockchain Sector Mapping Tool. Coinesk.

https://www.coindesk.com/us-government-announces-open-source-atlas-for-block chain-info

[34] Sarkis, J., Meade, L.M. and Talluri, S. (2004) E-Logistics and the Natural Environment. Supply Chain Management: An International Journal, 9, 303-312. https://doi.org/10.1108/13598540410550055

[35] Pradhan, R.P. and Bagchi, T.P. (2013) Effect of Transportation Infrastructure on Economic Growth in India: The VECM Approach. Research in Transportation Economics, 38, 139-148. https://doi.org/10.1016/j.retrec.2012.05.008

[36] Choon Tan, K., Lyman, S.B. and Wisner, J.D. (2002) Supply Chain Management: A Strategic Perspective. International Journal of Operations \& Production Management, 22, 614-631. https://doi.org/10.1108/01443570210427659

[37] Wang, D.F., Dong, Q.L., Peng, Z.M., Khan, S. and Tarasov, A. (2018) The Green Logistics Impact on International Trade: Evidence from Developed and Developing Countries. Sustainability, 10, 2235. https://doi.org/10.3390/su10072235

[38] Times Now (2017) Logistics Sector Given Infrastructure Status, to Help Boost GDP: Government.

[39] Singh, A.P. (2017) Keeping It Simple: Comparative Analysis of TFP across Manufacturing Industries and Major States of India. Theoretical Economics Letters, 7, 1821. https://doi.org/10.4236/tel.2017.76124

[40] Doshi, S., Madhavan, K. and Chandra, N. (2017) Supply Chain 2025-Trends \& Implications for India. A Joint A.T. Kearnet-CSCMP Study.

https://www.atkearney.com/operations-performance-transformation/article?/a/sup ply-chain-2025-trends-implications-for-india

[41] KPMG (2007) Skill Gap in the Indian Logistics Sector: A White Paper. KPMG Confederation of Indian Industry. http://www.in.kpmg.com/pdf/logistics.pdf

[42] Rastogi, V. (2018) What Is GST in India? Tax Rates, Key Terms and Concepts Explained. India Briefing, from Dezan Shira \& Associates.

https://www.india-briefing.com/news/what-gst-india-tax-rates-key-terms-concepts13962.html/

[43] Tuckey, J.C. (1977) U.S. Patent No. 4036395. U.S. Patent and Trademark Office, Washington DC.

[44] Durbin, J. and Watson, G.S. (1950) Testing for Serial Correlation in Least Squares Regression: I. Biometrika, 37, 409-428.

[45] Tabachnick, B.G. and Fidell, L.S. (2001) Using Multivariate Statistics. Allyn and Bacon, Needham Heights.

[46] Sahay, B.S. and Mohan, R. (2003) Supply Chain Management Practices in Indian Industry. International Journal of Physical Distribution \& Logistics Management, 33, 582-606. https://doi.org/10.1108/09600030310499277

[47] Singh, A.P. (2016) R\&D Spillovers \& Productivity Growth: Evidence from Indian Manufacturing. Indian Journal of Industrial Relations, 51, 563-579. 